Discussion Paper No. 08-020

The Impact of

Personal and Corporate Taxation on Capital Structure Choices

Michael Overesch and Dennis Voeller

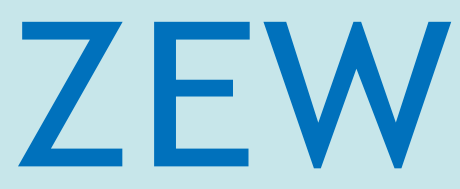

Zentrum für Europäische Wirtschaftsforschung $\mathrm{GmbH}$

Centre for European

Economic Research 
Discussion Paper No. 08-020

\title{
The Impact of Personal and Corporate Taxation on Capital Structure Choices
}

\author{
Michael Overesch and Dennis Voeller
}

Download this ZEW Discussion Paper from our ftp server:

ftp://ftp.zew.de/pub/zew-docs/dp/dp08020.pdf

Die Discussion Papers dienen einer möglichst schnellen Verbreitung von neueren Forschungsarbeiten des ZEW. Die Beiträge liegen in alleiniger Verantwortung der Autoren und stellen nicht notwendigerweise die Meinung des ZEW dar.

Discussion Papers are intended to make results of ZEW research promptly available to other economists in order to encourage discussion and suggestions for revisions. The authors are solely responsible for the contents which do not necessarily represent the opinion of the ZEW. 


\section{Non-Technical Summary}

Capital structure adjustments can be used to reduce the total tax burden on company investment since the taxation of the return on equity and debt capital differs in most countries. At the corporate level, interest payments reduce taxable profits while such a deduction is not feasible in the case of equity financing. At the shareholder level, effective tax rates on dividend and interest income differ as well. Therefore, the relative tax benefits of different sources of finance are supposed to have an impact on financing decisions. Theory suggests that both corporate profit tax and personal capital income taxes should be considered in order to analyze the tax impact on capital structure choices.

Since previous literature mainly focuses on the taxation of corporate profits, empirical evidence with respect to the possible impact of personal capital income taxation on capital structure choices is still scarce. Therefore, this paper aims at analyzing the effects from different taxation of equity and debt on capital structures of European firms while taking into account both personal and corporate income taxation. For the empirical analysis we employ a rich panel of firm-level financial accounting data of companies located in 23 European countries, taken from the AMADEUS data base. In contrast to other recent papers, we focus mainly on stand-alone companies. Furthermore, we collect detailed information about the tax systems of the considered countries during the period from 2000 until 2005.

The empirical results suggest that a higher tax benefit of debt has the expected significant positive impact on companies' financial leverage. Additional analysis confirms that debt ratios are affected by personal income taxation: the level of dividend taxes has a positive impact on the debt to assets ratio, whereas the taxation of personal interest income negatively affects corporate leverage. In addition, we find evidence that the capital structures of smaller companies react more heavily to higher tax benefits of debt. In contrast, this tax benefit only has a minor impact on the financial decisions of parent companies belonging to a group of affiliated firms. 


\section{Zusammenfassung (Summary in German)}

Anpassungen der Kapitalstruktur stellen ein geeignetes Mittel dar, um die Steuerbelastung von Unternehmen zu reduzieren. Die steuerliche Behandlung von Dividendenausschüttungen und Zinseinkünften unterscheidet sich in den meisten europäischen Länder sowohl auf Unternehmensebene als auch in der persönlichen Einkommensbesteuerung. So sind Zinsaufwendungen regelmäßig von der steuerlichen Bemessungsgrundlage abzugsfähig, während Dividendenzahlungen aus dem bereits versteuerten Unternehmensgewinn geleistet werden. Auch die persönliche Einkommensteuer der Anteilseigner knüpft häufig an die Art der Kapitaleinkünfte an. Es liegt daher nahe, einen Einfluss der steuerlichen Begünstigung eines bestimmten Finanzierungswegs auf betriebliche Finanzierungsentscheidungen zu vermuten. Aus theoretischer Sicht sollten bei einer Untersuchung des Einflusses steuerlicher Vorteile auf Finanzierungsentscheidungen sowohl Unternehmensteuern als auch die persönliche Kapitaleinkommensbesteuerung einbezogen werden.

Die bisherige empirische Literatur stellt häufig die Auswirkungen der Unternehmensbesteuerung auf Kapitalstrukturentscheidungen in den Mittelpunkt. Nur wenige Studien beziehen hingegen den Einfluss der persönlichen Besteuerung von Kapitaleinkünften ein. Daher analysiert dieser Beitrag die Wirkung der unterschiedlichen Besteuerung von Eigen- und Fremdkapital auf die Kapitalstruktur europäischer Unternehmen unter Berücksichtigung der Unternehmens- und der Kapitaleinkommensbesteuerung. Die Untersuchung basiert auf einem umfangreichen Panel mit Unternehmensdaten aus 23 europäischen Ländern, das der AMADEUS Datenbank entnommen wurde. Anders als in anderen jüngst erschienenen Beiträgen stehen in unserer Studie schwerpunktmäßig konzernunabhängige Firmen im Mittelpunkt. Zur Erfassung der steuerlichen Finanzierungsanreize verwenden wir detaillierte Informationen über Steuersysteme und Steuertarife der betrachteten Länder im Zeitraum von 2000 bis 2005 .

Die empirischen Ergebnisse legen es nahe, dass ein steuerlicher Vorteil der Fremdfinanzierung 
wie erwartet den Verschuldungsgrad erhöht. Weiterführende Analysen bestätigen, dass die Fremdkapitalquote von Unternehmen durch die persönliche Besteuerung von Kapitaleinkünften beeinflusst wird: Die Höhe des Steuersatzes auf Dividendeneinkünfte hat einen positiven Einfluss auf die Fremdkapitalquote, während eine höhere Besteuerung von Zinseinkünften den Verschuldungsgrad von Unternehmen senkt. Darüber hinaus finden wir einen stärkeren Effekt der Besteuerung auf die Kapitalstruktur bei kleineren Gesellschaften, wohingegen dieser Einfluss bei Muttergesellschaften von Konzernen schwächer zu sein scheint. 


\title{
The Impact of Personal and Corporate Taxation on Capital Structure Choices $\ddagger$
}

\author{
Michael Overesch * \\ (ZEW ) \\ Dennis Voeller ** \\ (University of Mannheim)
}

March 2008

\begin{abstract}
This paper empirically analyses whether both personal and corporate taxation have an impact on companies' capital structure decisions. We investigate the effect of the difference in taxation of debt and equity financing on capital structures. Our empirical results, based on a comprehensive panel of European firm-level data, suggest that a higher tax benefit of debt has the expected significant positive impact on a company's financial leverage. Particularly, we find evidence that the capital structures of smaller companies respond more heavily to changes in the tax benefit of debt. Additional analysis confirms that not only corporate taxes are relevant for corporate financial planning, but variation in capital income tax rates at the shareholder level implicates significant capital structure adjustments as well. Moreover, we find substitutive relationships between non-debt tax shields and the effect of the corporate tax rate on capital structures.
\end{abstract}

Keywords: Capital Structure, Corporate Income Tax, Personal Income Tax, Firm-Level Data

JEL Classification: G30, G32, H24, H25

$\ddagger$ The authors would like to thank Ulrich Schreiber, Dirk Simons, Volker Vonhoff and seminar participants at the IX Workshop on Quantitative Finance in Rome for very valuable comments on an earlier draft. All remaining errors are the responsibility of the authors.

* Centre for European Economic Research (ZEW), L 7,1, D-68163 Mannheim, Germany, +49 6211235 394, overesch@zew.de.

** University of Mannheim, Department of Business Administration, Schloss, D-68161 Mannheim, Germany, +496211811638, voeller@bwl.uni-mannheim.de. 


\section{Introduction}

Capital structure decisions are likely to affect companies' tax payments, since corporate taxation typically distinguishes between different sources of finance. Interest payments can generally be deducted from taxable profits while such a deduction is not available in the case of equity financing. Taxation of capital income at the shareholder level often differentiates between the types of capital as well. Therefore, it can be expected that the relative tax benefits of different sources of finance have an impact on financing decisions. Theory suggests that both corporate profit tax and personal capital income taxes should be considered in order to analyze the tax consequences of capital structure choices more accurately (Graham, 2003).

Previous empirical literature dealing with tax effects on capital structure choices has often focused solely on the taxation of corporate profits, thereby neglecting capital income taxation at the shareholder level. Empirical evidence with respect to the possible impact of personal capital income taxation on capital structure choices is still scarce. However, studies considering these aspects (Givoly et al., 1992; Graham, 1999; Alworth and Arachi, 2001; Gordon and Lee, 2001, 2007) find significant effects of personal taxation. While previous studies are based on data from one single country, mainly the US, empirical evidence for an international sample of companies is generally lacking. Employing an international dataset may yield generalizable findings which are not bound to specific national characteristics in tax regimes and capital market conditions. Therefore, this paper aims at analyzing the effects from different taxation of equity and debt on capital structures of European firms.

Tax incentives for using a particular source of finance differ significantly among European countries. Moreover, during the last decade, considerable reforms of company and capital income taxation have been implemented in Europe. For instance, 18 out of 23 countries included in our sample have altered their corporate tax rate at least once between 2000 and 2005. Top statutory tax rates on personal income were altered in 17 countries during this 
period. Tax reforms have been set up predominantly in order to enhance fiscal conditions for internationally mobile capital and profits. Furthermore, equal tax rates for all types of personal capital income have been preferred by national legislators for administrative reasons. Given that interest payments and dividends are taxed differently at the company level, this could lead to effective unequal treatment of debt and equity. Germany, for example, has adopted a significant tax reform which will result in a massive tax incentive for debt financing in 2009. Therefore, we are interested in how flexible capital structure decisions are with respect to taxation, given a bunch of non-tax determinants of capital structures. If a company's capital structure decision is significantly restricted by nontax factors, distortions of financial decisions due to taxation may lead to inefficiencies in investment decisions and risk allocation. Thus, evidence about the tax effects on capital structures for European firms would be expedient.

For the empirical analysis we employ European firm-level data taken from the AMADEUS database provided by Bureau van Dijk. We use a rich panel of firm-level financial accounting data of companies located in 23 European countries. In contrast to other recent papers, we focus mainly on stand-alone companies. Compared to firms which belong to a company group, these companies feature minor opportunities for internal financing. Relying on capital from outside investors, it can be presumed that stand-alone companies are particularly affected by variations in personal income tax rates. Furthermore, we collect detailed information about the tax systems of the considered countries during the period from 2000 until 2005. Since corporate taxation and personal income taxation vary among countries and have often been amended during the considered period, our identification strategy relies on the international variation of the tax variables. The empirical results clearly suggest that a higher tax benefit of debt has the expected significant positive impact on companies' financial leverage. Additional analysis confirms that fractions of debt are affected by personal income taxation: the level of dividend taxes has a positive impact on the debt to assets ratio, whereas the taxation of personal interest income negatively affects corporate leverage. Furthermore, we find evidence that the capital structures of 
smaller companies react more heavily to higher tax benefits of debt. In contrast, this tax benefit only has a minor impact on the financial decisions of parent companies belonging to a group of affiliated firms.

The remainder of the paper is organised as follows. In Section 2 we briefly review theoretical and empirical literature dealing with tax and non-tax determinants of capital structure. Section 3 describes the institutional background of European taxation systems and the dataset we are using. Regression estimates are reported in Section 4. Finally, Section 5 concludes.

\section{Theoretical Background}

Value relevance of capital structure choice and the impact of taxation on financing and investment decisions have been subject to extensive prior discussion in finance literature. Although the rationale of Modigliani and Miller (1958) who propose the irrelevance of capital structure for firm value in perfect capital markets has been generally accepted, the presence of financial innovation and the high cost of corporate financial decision making seem to provide evidence for the value relevance of financial structure choice (Ross, 1977; Myers, 2001).

For the purpose of this paper, literature following Modigliani and Miller's seminal paper (for a review see Myers, 2001; Graham, 2003) can be classified into two streams: a) papers which focus on taxation as a determinant of capital structure and b) 'non-tax approaches' which centre bankruptcy costs as well as governance and information aspects of capital structure choice. As our focus lies on the effects of taxation, we refer to the latter stream of literature only in order to employ adequate control variables. 


\subsection{Capital Structure Choice and Taxation}

While suggesting a fundamental irrelevance of financial decisions for firm value, Modigliani and Miller already refer to company taxation as a reason for preferring debt to equity (Modigliani and Miller, 1958). Within their framework of perfect capital markets, the value of a permanently leveraged firm is generated by adding the value of the corporate tax shield of debt to the value of an identical but unleveraged company (Modigliani and Miller, 1963). Even though there is still an ongoing debate about the calculation of the value of the tax shield (see e.g. Fernandez, 2004, 2005; Fieten et al., 2005; Cooper and Nyborg, 2006), the proposed tax advantage of debt would empirically imply a corner solution.

Miller (1977) develops a broader perspective on tax incentives by explicitly integrating personal income taxation into his model. He concludes that, under existing personal tax concessions made to equity income, there is no optimal capital structure for any single firm (Miller, 1977). In contrast, De Angelo and Masulis develop a theoretical explanation for the existence of a firm-specific optimal debt to equity ratio by taking alternative paths to reduce the corporate tax burden (e.g., depreciation allowances) into account. While a company's effective marginal tax rate on interest deduction depends on these non-debt tax shield substitutes and declines as leverage increases, the marginal personal tax disadvantage of interest income remains constant (De Angelo and Masulis, 1980). This leads to a unique interior optimum, even in the absence of any non-fiscal incentives (such as bankruptcy costs etc.).

Examining De Angelo's and Masulis' hypothesis, MacKie-Mason (1990) finds supporting empirical evidence by analyzing US firms' probability of preferring debt over equity issues. As De Angelo and Masulis proposed, existing loss carryforwards (and investment tax credits) diminish the effective tax advantage of debt. Using a matched pairs approach, Graham and Tucker (2006) find evidence that non-debt tax shields caused by tax shelters act as a substitute for the use of debt. In their sample consisting of 76 firms, the 38 firms using tax 
shelters have debt ratios that are more than 5 percent lower than those of their matches.

Empirical researchers face the problem of identifying sufficient cross-sectional or timeseries variation in firm-specific tax incentives when using a one-country sample. One stream of studies (for a review see also Graham, 1996b; Alworth and Arachi, 2003; Weichenrieder, 2006) consequently focuses on a more detailed view of effective corporate tax incentives. Instead of using indirect proxies for the effective tax advantage of debt, Graham (1996a, 2000) calculates firm-specific marginal corporate tax rates. By employing a random walk simulation of future corporate earnings, he is able to show that taxation causes changes in corporate leverage ratios. Examining a dataset of Italian companies, Alworth and Arachi (2001) use the variation in additional tax savings due to differences in profitability or because of an existing loss carryforward. Gropp (2002) investigates the effects of crosssectional variation in corporate tax rates. He employs regional variation in German local tax rates and identifies a positive effect of higher tax rates on the use of debt.

Using international accounting and tax data rather than a mere national sample seems to be an appropriate way of meeting the concerns that empirical results arise from the specifics of a particular national tax code. While prior empirical studies focus on samples with exclusively domestic companies, Rajan and Zingales (1995) analyse an international dataset consisting of companies from the G-7 countries. They find a positive aggregate correlation between net tax advantages and average leverage changes in five out of seven countries. Newberry and Dhalival (2001) find that the bond issuance location of U.S. multinationals is affected by the respective tax rates in their subsidiaries' host countries, as well as by the existence of domestic tax-loss carryforwards. Moore and Ruane (2005) and Huizinga, Laeven and Nicodème (2008) state a positive impact of the local tax rate as well as of tax differentials across countries on the financial leverage of European multinationals' affiliates.

Whereas there are several other studies on the impact of corporate taxation on financing decisions, one very rarely comes across empirical evidence featuring international varia- 
tion in personal taxation. This could be due to the fact that the focus of many recent studies lies on multinationals with enhanced internal financial planning opportunities (see e.g. Jog and Tang, 2001; Desai, Foley and Hines, 2004; Buettner and Wamser, 2007; Buettner et al., 2008). Earlier studies considering personal income taxation are mainly based on single country samples. Givoly et al. (1992) find a negative impact of differences in dividend yields on changes in leverage of US firms. They interpret this result as an indirect indicator for the impact of personal taxation. Graham (1999) analyses the effects of personal income taxation using cross-sectional differences in US companies' payout ratios in order to estimate the variation in personal income tax. He determines a potential net tax advantage of debt by subtracting the 'personal tax penalty' from the marginal corporate tax rate. This 'penalty' is induced by a higher personal taxation of interest compared to dividend payments and capital gains. Depending on the respective design of the tax code, its amount varies with a company's payout policy. Although it does not imply any cross-sectional variation in statutory personal interest tax rates, Graham's model yields significant cross-sectional effects of personal income taxation. Following a similar approach, Alworth and Arachi (2001) find cross-sectional as well as time-series effects of personal income taxation for a sample of Italian companies. Gordon and Lee (2001, 2007) who explicitly include personal tax rates imposed on interest income find that personal income taxation has significant and considerable adverse effects on the debt to assets ratio of US firms.

We extend the scope of former international studies dealing with tax impacts on capital structures to personal income taxation. Using tax data from 23 European countries provides us with cross-sectional variation in personal tax rates and with greater intertemporal variation. Like Rajan and Zingales (1995), we use the top personal tax rate to calculate the net tax benefit of debt. Unlike their groundbreaking paper, we use regression analysis in order to control for 'non-tax' determinants of capital structure choice. Following Graham (1999), we consider the tax consequences of debt relative to equity. If we denote the corporate profit tax rate by $\tau^{C}$, the additional personal income tax rate on dividend income 
by $\tau^{D}$, and the combined corporate and personal income tax rate on interest income by $\tau^{I}$, then the tax benefit from debt financing relative to equity financing $\Delta$ can be written as

$$
\Delta=\left(\tau^{C}+\tau^{D}\right)-\tau^{I}
$$

The term inside the brackets constitutes the total tax burden in the case of equity finance and the second term shows the effective tax level in the case of debt finance. The higher $\Delta$ is, the higher the relative tax benefit from interest deductions. Note that $\Delta$ implies an immediate profit distribution. In our empirical analysis, we will also relax this strict assumption. As a result, the effect of the dividend tax should decrease while an additional impact of capital gains taxes $\tau^{G}$ is to be expected.

\subsection{Capital Structure Choice and Non-Tax Factors}

In order to isolate the impact of corporate and personal taxation on capital structure choices, several non-tax factors influencing corporate financing have to be considered (Harris and Raviv, 1991; Myers, 2001, Beattie, Goodacre and Thomson, 2006). The most prominent factors in finance literature are bankruptcy costs, agency conflicts, and information asymmetry. Furthermore, as we examine an international sample, institutional and macroeconomic differences across countries have to be controlled for. For example, Rajan and Zingales (1995) examine the impact of the banking system on leverage but find no significant effects. La Porta et al. (1997) consider investor protection across 49 countries and show that the respective legal environment has an impact on debt and equity financing.

It is also quite possible for variation in macroeconomic factors to influence capital structure choices over time. De Angelo and Masulis (1980) propose that a higher inflation promotes debt financing by inducing a decline in the real value of non-debt tax shields. In contrast, Huizinga, Laeven and Nicodème (2008) explain their finding of a negative effect of inflation 
on debt financing by pointing to a higher risk premium on debt obligations within an inflationary environment. The corporate interest rate could constitute another determinant of capital structure. A higher cost of debt relative to equity financing should lead to a shifting of financial sources. However, firm-specific interest rates are likely to be endogenous with capital structure choices.

At the company level, potential costs of financial distress could be a determinant of capital structure choice. The trade-off theory suggests that a company's optimal leverage lies at the point where incremental tax advantages and disadvantages from increased risk of financial distress are equal. Therefore, profitable firms with a lower risk of financial distress should have a higher leverage. The pecking order theory predicts higher leverage only for profitable companies whose internal cash flows outbalance real investment opportunities (ShyamSunder and Myers, 1999). Agency conflicts between management and different groups of investors could also be a reason for variation in capital structure. For instance, Jensen (1986) considers increased leverage as a means of reducing management discretion. For companies with limited growth opportunities, interest payments made with free cash flows could avoid unprofitable investments by the management. Thus, the impact of profitability on the debt ratio is not clear.

The value of total assets indicating company size may also affect firm's financial structure. For example, it might represent a proxy for the quality of information available to outside investors because disclosure regulations are often linked directly or indirectly to size criteria (Chan, Faff and Ramsay, 2005). Reduced uncertainty due to high quality information could encourage equity issues which are informationally sensitive. This would lead to a lower leverage (Rajan and Zingales, 1995). Harris and Raviv (1990) find a positive correlation between companies' liquidation value (proxied by the fraction of tangible assets) and the optimal debt level. An increase in the liquidation value makes a liquidation less costly for shareholders as well as for debt holders, who can resort to liquidation in order to attain a more effective management control. 
For the empirical analysis, we will consider several firm-level variables such as profitability, size or tangibility to control for the above mentioned non-tax determinants of capital structure. Furthermore, company-specific fixed effects will be used to control unobserved firm-specific differences which are time-invariant. Therefore, we are able to control for determinants such as industry, as well as product and customer characteristics which are analysed in recent empirical studies (e.g., Kale and Shahrur, 2007), provided that they remain constant over time.

\section{Description of the Data}

For the empirical analysis it is crucial to have sufficient variations in the tax variables. In this section, we examine the respective tax institutions during the period from 2000 until 2005 in European countries. Furthermore, we describe the firm-level financial accounting data and other control variables used.

\subsection{Personal and Corporate Taxation}

In Europe, tax systems are very distinct. Typically, taxation of company profits depends on the type of capital. With regard to equity capital, the corporate profit tax and dividend taxation at the shareholder level must be considered. In the case of debt financing, interest payments for debt capital can be deducted from taxable profits at the corporate level. However, it is necessary that restrictions of the interest deductibility are considered in several countries. Moreover, taxation of interest as personal income also leads to a tax burden on debt financing. During the considered time period from 2000 until 2005, several amendments of company tax systems took place in European countries. As a result variation in the tax variables can be ascribed to changes in the corporate tax rate (mainly tax rate cuts), on the one hand, and to several amendments of personal capital income 
taxation, on the other hand. The latter include changes of personal income tax rates and reforms relating to the integration of corporate taxation into the personal income tax.

From 2000 until 2005, several tax rate cuts of the statutory corporate profit tax rate came into force. With regard to all 23 European countries covered in our sample ${ }^{1}$, the mean corporate tax rate $\tau^{C}$ constituted $30.5 \%$ in 2000 and fell to $25.3 \%$ in 2005 . Only five of these 23 countries did not reduce their corporate tax rate during the considered six-year period. Table 1 presents tax rates on corporate income (column 2) as well as effective dividend and interest tax rates at the shareholder level (columns 3 and 4) for the year 2005 .

For the empirical analysis, we assume that the shareholder falls within the top income tax brackets in the same country in which the company is located. ${ }^{2}$ Furthermore, we accurately calculate the effective additional tax payment as percentage of the net dividend distribution depending on the type of tax system. The additional dividend tax is referred to as $\tau^{D}$, i.e. the effective tax rate imposed on distributed profits is compiled. Due to several amendments of dividend tax rates and changes in the integration of corporate and personal income taxation, the mean effective dividend tax level of the 23 countries examined increased slightly from 14.3 per cent in 2000 to 14.8 per cent in 2005 . In 18 countries, the tax level on dividends changed at least once during the six-year period.

The taxation of dividends at the shareholder level depends on the integration system of corporate taxation into personal income taxation. In principle, three categories of tax systems can be distinguished: classical tax systems, shareholder relief systems, and imputation systems. In the case of the so-called classical system, dividends are taxed by the personal income tax rate without any relief. Thus, this system, which is applied in our

1 See Table 1 for a list of all considered countries.

2 We do not have detailed information about the tax situation of the shareholders. It seems reasonable to assume that the relevant shareholder is taxed in the top tax brackets, since only shareholders with comparably high amounts of capital interest are able to influence company financing decisions materially. 
sample in Ireland and Switzerland, leads to a double taxation of distributed profits, since the dividend tax adds to the corporate tax at the company level. For Ireland, e.g., the additional effective tax burden on distributed profits at the shareholder level (see column 3 of Table 1) is calculated by multiplying the remaining distributable profits after corporate taxation with the top statutory tax rate on dividends: $(1-0.125) 0.42=0.3675$.

Table 1: Effective Tax Rates in Europe 2005

\begin{tabular}{lccccc}
\hline Country & $\tau^{C}$ & $\tau^{D}$ & $\tau^{I}$ & $\tau^{G}$ & Integration system \\
\hline Austria & 0.2500 & 0.1875 & 0.2500 & 0.1875 & Shareholder-relief \\
Belgium & 0.3399 & 0.1650 & 0.1500 & 0.0000 & Shareholder-relief \\
Czech Republic & 0.2600 & 0.1110 & 0.1500 & 0.0000 & Shareholder-relief \\
Estonia & 0.0000 & 0.2400 & 0.0000 & 0.2400 & Shareholder-relief \\
Finland & 0.2600 & 0.1181 & 0.2800 & 0.2072 & Shareholder-relief \\
France & 0.3493 & 0.2199 & 0.2700 & 0.1757 & Shareholder-relief \\
Germany ${ }^{a}$ & 0.3947 & 0.1341 & 0.5085 & 0.1341 & Shareholder-relief \\
Greece & 0.3200 & 0.0000 & 0.1000 & 0.1360 & Shareholder-relief \\
Hungary & 0.1771 & 0.2057 & 0.0171 & 0.2057 & Shareholder-relief \\
Iceland & 0.1800 & 0.0820 & 0.1000 & 0.0820 & Shareholder-relief \\
Ireland & 0.1250 & 0.3675 & 0.2000 & 0.1750 & Classical \\
Italy & 0.3725 & 0.0784 & 0.1675 & 0.1114 & Shareholder-relief \\
Latvia & 0.1500 & 0.0000 & 0.2500 & 0.0000 & Shareholder-relief \\
Luxembourg & 0.3038 & 0.1356 & 0.3895 & 0.1356 & Shareholder-relief \\
Netherlands & 0.3150 & 0.1713 & 0.2500 & 0.1713 & Shareholder-relief \\
Norway & 0.2800 & 0.0000 & 0.2800 & 0.0000 & Imputation \\
Poland & 0.1900 & 0.1539 & 0.1900 & 0.1539 & Shareholder-relief \\
Portugal & 0.2500 & 0.1500 & 0.2000 & 0.0000 & Shareholder-relief \\
Slovak Republic & 0.1900 & 0.0000 & 0.1900 & 0.1539 & Shareholder-relief \\
Slovenia & 0.2500 & 0.2438 & 0.5000 & 0.0000 & Shareholder-relief \\
Spain & 0.3500 & 0.1495 & 0.4500 & 0.0975 & Imputation \\
Switzerland & 0.2132 & 0.3176 & 0.4036 & 0.0000 & Classical \\
United Kingdom & 0.3000 & 0.1750 & 0.4000 & 0.1000 & Imputation \\
\hline
\end{tabular}

$\tau^{C}$ denotes the corporate tax rate on company profits including local profit taxes. $\tau^{D}$ denotes the effective additional tax burden on distributed profits due to dividend taxation at the shareholder level. The effective tax rate on interest income $\tau^{I}$ includes interest deductability restrictions at the corporate level. $\tau^{G}$ denotes the effective tax on capital gains in case of a qualified shareholding. The tax data are collected from several annual volumes of the European Tax Handbook edited by the International Bureau of Fiscal Documentation (IBFD) and from international tax surveys provided by Ernst\&Young, PwC and KPMG. a) We assume the mean multiplier of the local trade tax of municipalities, which have a minimum of 50.000 inhabitants each. Church taxes are not considered. ${ }^{b)}$ The canton of Zurich is taken into consideration.

If interest payments can be deducted from taxable profits at the company level and are 
taxed at the same tax rate as dividend income, equity finance is obviously discriminated in the case of a classical system. For this reason, so-called shareholder-relief systems have lower tax levels on dividends compared to other personal income. Typical methods of relief are the application of a lower tax rate on dividend income or the full or partial tax exemption of dividends. In Austria, e.g., dividends were subject to a reduced statutory tax rate of $25 \%$ in 2005 , compared to a top income tax rate of $50 \%$. Therefore, the effective additional tax burden of distributed profits at the shareholder level (see column 3 of Table 1) results in: $(1-0.25) 0.25=0.1875$.

Shareholder-relief systems are widespread among the considered European countries and have increased in popularity ever since the third method of dividend taxation, the socalled imputation method, has been abolished in several European countries. ${ }^{3}$ Under an imputation system, double taxation of distributed dividends is avoided or mitigated by means of an imputation credit. Corporate tax payments can be credited, to some extent, against the dividend tax liabilities of the shareholder. This leads to smaller effective dividend tax payments. For example, in 2005 a tax credit of one ninth of the paid dividend could be set off against the shareholders' tax liability in the United Kingdom. Under the top statutory tax rate on dividends $\tau^{D}$ adds up to $\left(1-0.3+\frac{1}{9} 0.7\right) 0.325-\frac{1}{9} 0.7=0.175$. In 2000 , six of the considered 23 countries had an imputation system, whereas in 2005 only three imputation systems were still in force. ${ }^{4}$ In 2008 only one of the considered countries, the United Kingdom, still uses an imputation system.

In the case of debt financing, interest payments for debt capital can be deducted from taxable profits at the corporate level. However, paid interest must be taxed at the level of the lender, for example, as personal income. This is particularly relevant if the shareholders

${ }^{3}$ Imputation systems were abolished because the restriction of imputation systems to pure domestic dividend distributions is contrary to European law (Cf. ECJ of 9.7.2006, C-319/02 (Maninnen); ECJ of 3.6.2007, C-292/04 (Meilicke)).

${ }^{4}$ In 2000 the following countries had an imputation system in place; the year of abolishment is indicated in parentheses: Finland (2005), France (2005), Germany (2001), Norway (2006), Spain (2007), the United Kingdom. 
provide their company with additional capital by means of shareholder loans. In accordance with the assumption made in the case of dividend taxation, we assume that the lender is taxed in the top income tax brackets in the same country in which the company is located. Moreover, at some locations, interest deductibility at the corporate level is restricted to some extent. In this case, an additional tax burden on debt financing must be considered. For example, in the case of the Italian local tax $(I R A P)$ no interest deduction is allowed. In the case of the German trade tax (Gewerbesteuer), only half of all interest payments could be deducted. We take such an additional tax burden into consideration when constructing the effective tax rate on interest, denoted by $\tau^{I}$. Several changes of the tax rate on interest income provide some variation in that variable. During the considered period, the mean tax rate on interest of the 23 investigated countries fell from 27.2 per cent to 24.8 per cent.

Capital structure choices depend on the relative tax effects of different sources of finance. Therefore, we construct the tax benefit from debt financing relative to equity financing in accordance with expression (1) as $\left(\tau^{C}+\tau^{D}\right)-\tau^{I}$. Table 2 shows the tax benefit of debt in each of the considered 23 countries and for each year during the period of 2000 until 2005. Most tax systems of the regarded countries discriminate equity-financed investments against debt financing. In 2005, for instance, we can observe a positive tax benefit of debt in 19 of the 23 considered countries.

Finally, if corporate profits are partly retained, the choice between equity and debt financing may be affected by the taxation of capital gains, since a shareholder can sell shares before profits are distributed. The taxes on capital gains can cause an increase of the cost of capital in the case of equity financing, and thus, higher capital gains taxes may lead to a smaller share of equity capital. However, the impact of capital gains taxes depends on the opportunity to deduct the purchase price of the shares from the taxable amounts. In accordance with the assumptions about dividend and interest income tax, we assume a qualified shareholding and taxation at the top income tax brackets. The effective tax rate imposed on capital gains $\tau^{G}$ is calculated assuming that corporate taxes are capitalized at 
Table 2: Tax Benefit of Debt Relative to Equity

\begin{tabular}{lrrrrrr}
\hline Country & 2000 & 2001 & 2002 & 2003 & 2004 & 2005 \\
\hline Austria & 0.2550 & 0.2550 & 0.2550 & 0.2550 & 0.2550 & 0.1875 \\
Belgium & 0.3414 & 0.3414 & 0.3414 & 0.2889 & 0.2889 & 0.3549 \\
Czech Republic & 0.2635 & 0.2635 & 0.2635 & 0.2635 & 0.2380 & 0.2210 \\
Estonia & 0.2600 & 0.2600 & 0.2600 & 0.2600 & 0.2600 & 0.2400 \\
Finland & 0.0000 & 0.0000 & 0.0000 & 0.0000 & 0.0000 & 0.0981 \\
France & 0.3882 & 0.3737 & 0.3632 & 0.3342 & 0.2906 & 0.2992 \\
Germany ${ }^{a}$ & 0.0301 & -0.0278 & -0.0278 & -0.0166 & -0.0019 & 0.0203 \\
Greece & 0.2500 & 0.2500 & 0.2500 & 0.2500 & 0.2500 & 0.2200 \\
Hungary & 0.3407 & 0.3407 & 0.3407 & 0.3407 & 0.3243 & 0.3657 \\
Iceland & 0.2700 & 0.2700 & 0.1620 & 0.1620 & 0.1620 & 0.1620 \\
Ireland & 0.3712 & 0.3320 & 0.3128 & 0.2925 & 0.2925 & 0.2925 \\
Italy & 0.3184 & 0.3097 & 0.3097 & 0.2922 & 0.2834 & 0.2834 \\
Latvia & 0.0000 & 0.0000 & -0.0300 & -0.0600 & -0.1000 & -0.1000 \\
Luxembourg & 0.0505 & 0.0787 & 0.0499 & 0.0499 & 0.0499 & 0.0499 \\
Netherlands & -0.0875 & 0.2625 & 0.2588 & 0.2588 & 0.2588 & 0.2363 \\
Norway & 0.0000 & 0.0000 & 0.0000 & 0.0000 & 0.0000 & 0.0000 \\
Poland & 0.2400 & 0.1880 & 0.1880 & 0.1795 & 0.1539 & 0.1539 \\
Portugal & 0.2764 & 0.2764 & 0.2400 & 0.2400 & 0.2000 & 0.2000 \\
Slovak Republic & 0.2465 & 0.2465 & 0.2125 & 0.2125 & 0.0000 & 0.0000 \\
Slovenia & -0.0250 & -0.0250 & -0.0250 & -0.0250 & -0.0250 & -0.0062 \\
Spain & 0.0495 & 0.0495 & 0.0495 & 0.0495 & 0.0495 & 0.0495 \\
Switzerland ${ }^{b)}$ & 0.1409 & 0.1444 & 0.1441 & 0.1437 & 0.1437 & 0.1272 \\
United Kingdom & 0.0750 & 0.0750 & 0.0750 & 0.0750 & 0.0750 & 0.0750 \\
\hline & & & & & & \\
\hline & & & & &
\end{tabular}

The tax benefit of debt relative to equity is calculated according to $\left(\tau^{C}+\tau^{D}\right)-\tau^{I}$, where top personal income tax brackets are assumed. The tax data are collected from several annual volumes of the European Tax Handbook edited by the International Bureau of Fiscal Documentation (IBFD) and from international tax surveys provided by Ernst\&Young, PwC and KPMG. ${ }^{a}$ ) We assume the mean multiplier of the local trade tax of municipalities, which have a minimum of 50.000 inhabitants each. Church taxes are not considered. ${ }^{b)}$ The canton of Zurich is taken into consideration.

the expense of the selling shareholder. In additional sensitivity analyses we also consider tax rates in the case of non-qualified shareholding. ${ }^{5}$

${ }^{5}$ Differences in the capital gains taxation between qualified shareholding (above certain threshold of participation) and non-qualified shareholding are relevant in the case of Austria, Belgium, Germany, Italy, Luxembourg, Netherlands, Slovenia, and the United Kingdom. 


\subsection{Data Set}

Firm-level data are taken from the AMADEUS database provided by Bureau van Dijk. AMADEUS is a comprehensive firm-level database, which contains publicised information about European companies in a standardised format. However, publication obligations and enforcements differ significantly between countries. Therefore, the distribution of the considered companies does not have to reflect the distribution of companies among European countries. German companies, for example, represent only less than $1 \%$ of all considered companies in the data set, which is obviously an underreporting. Moreover, complete data on financial accounting is not always available in the AMADEUS database, although the firm is generally included in the database. We therefore restrict the sample to companies, for which financial accounting data of at least two successive years in the time period from 1999 until 2005 is available. ${ }^{6}$ Thus, we are able to control for the heterogeneity between individual firms by means of a simple within transformation (cf. Lemmon, Roberts and Zender, 2008). Since we are interested in the effect of the corporate tax system on capital structure choices, we only employ data of incorporated companies. Observations of the financial sector as well as observations without an industry classification are not included either. ${ }^{7}$ Furthermore, we use detailed annual information about the company group structures and focus exclusively on corporations that are not controlled to more than $50 \%$ by another corporation during the considered period. ${ }^{8}$ Finally, our sample contains firm-level data of corporations located in 23 European countries. In addition to 20 member states of the European Union, Iceland, Norway and Switzerland are also included. ${ }^{9}$

${ }^{6}$ We also remove observations with implausible financial accounting data such as unequal total assets and total capital employed or implausible high profits or losses.

7 We employ the Nomenclature générale des activités économiques (NACE) industry classification.

8 In the case of subsidiaries, intercompany debt seems to be an important source of finance (Desai, Foley, Hines, 2004). Since we are interested in the effects of personal income taxation on the shareholder level, we remove subsidiaries from our sample. Furthermore, all companies which switch between stand-alone and group-member status during the considered period from 2000 until 2005 are removed.

9 Although generally covered by the database, no data are included from the EU member states Denmark and Sweden because the data export is limited in the case of these countries for technical reasons. In case of Lithuania, no data are provided which have a complete set of firm-level variables. Moreover, 
The firm-level variables are taken from the financial accounting data provided by the AMADEUS database. In our empirical analysis we employ, as the dependent variable, the debt to assets ratio calculated as the fraction of debt to total assets using the respective firm-level data from financial accounting. Furthermore, we use a dummy variable indicating if a company has a loss carryforward. The dummy equals one if the respective company's profit in the previous year was negative. Otherwise, the dummy is zero. ${ }^{10}$ Hence, we generally lose one observation of each considered company, in particular all the observations in 1999. A company which has a loss carryforward can offset former losses with current profits for tax purposes. Due to this non-debt tax shield the tax elasticity with regard to interest deduction should be lower.

The size of the business activity may have an indirect impact on the accession to external finance (e.g., Gordon and Lee, 2001). For instance, since it may be an indicator for the level of disclosure, it could influence the firm-specific cost of external capital. Therefore, we use the natural log of total assets as an indicator for the firm size.

Tangibility as the share of tangible assets in total assets is considered as an additional firmlevel control variable. However, the expected impact on the use of debt is ambiguous. On the one hand it can be assumed that higher tangibility can be regarded by creditors as an increasing amount of collateral. In this case, the access to additional debt should be easier, since agency costs of debt are reduced by the value of collateral. On the other hand, interest deduction may be crowded out by the non-debt tax shields generated by depreciation and investment tax credits related with tangible assets (DeAngelo and Masulis, 1980).

In accordance with previous studies analysing determinants of the capital structure choice, we control for variations in companies' profitability. ${ }^{11}$ The EBITDA to assets ratio is

continuous data of group structures are not available in the cases of Bulgaria, Cyprus, Malta, and Romania.

10 Obviously this can only be a rough indicator for a tax loss carryforward. However, detailed information on accumulated losses as stated in companies' tax statements is not available for our sample.

11 See, e.g., Rajan and Zingales (1995), Graham (2000). 
Table 3: Descriptive Statistics

\begin{tabular}{llrr}
\hline Variable & Definition & Mean & Std.Dev. \\
\hline \multicolumn{1}{c}{ Firm level variables } \\
Debt to Assets Ratio & Total debt in total assets & \\
Loss Carryforward & Loss in previous year, binary & .676 & .229 \\
Total Assets & Total assets stocks in $€$ thousand & 247,564 & $3,904,887$ \\
Tangibility & Tangible assets in total assets & .236 & .233 \\
Profitability & EBITDA to total assets & .113 & .159 \\
& $\quad$ Tax variables & & \\
$\tau^{C}$ & Statutory corporate income tax rate & .347 & .069 \\
$\tau^{D}$ & Effective tax rate on dividends & .159 & .072 \\
$\tau^{I}$ & Effective tax rate on interest income & .281 & .132 \\
$\left(\tau^{C}+\tau^{D}\right)-\left(\tau^{I}\right)$ & Tax benefit of debt relative to & .225 & .137 \\
$\tau^{G}$ & equity income & & \\
& Effective tax rate on capital gains & .121 & .056 \\
& on the disposal of shares & & \\
Inflation Rate & $\quad$ Further country characteristics & & \\
GDP & Inflation rate & .026 & .009 \\
\hline
\end{tabular}

The descriptive statistics are based on a sample of stand-alone companies and parent companies of a group of affiliated companies. The sample includes 3,181,931 observations of companies during the period from 2000 until 2005. The firm-level data are taken from the AMADEUS database provided by Bureau van Dijk. The version used here contains data from 1999 until 2005. Tax data are taken from several annual volumes of the European Tax Handbook edited by the International Bureau of Fiscal Documentation (IBFD) and from tax surveys provided by Ernst\&Young, $\mathrm{PwC}$ and KPMG. Other country variables such as nominal GDP in US dollars and inflation rates originate from World Bank World Development Indicators (2006).

used in order to avoid endogeneity problems. As explained in Section 2.2, due to conflicting theories about capital structure choice the predicted sign of the coefficient remains undetermined.

With respect to the country-level variables, the tax variables described in Section 3.1 are of particular interest. We collect the statutory corporate income tax rates adjusted for additional surcharges and other profit taxes at the company level. Furthermore, effective dividend tax rates, which consider the type of tax system and the profit taxation at the company level, are calculated. Moreover, we calculate effective tax rates imposed on inter- 
est income, which are modified by restrictions on interest deductions at the corporate level. Finally, for additional regressions, we also collect effective tax rates on capital gains from the disposal of shares. The detailed description of the tax data in Section 3.1 suggests that we have sufficient variations available in the tax data. Due to the fact that the respective tax reforms came into force in different years, we should be able to distinguish between tax effects and macro-economic time effects.

Furthermore, we consider the inflation rate as a country-level control variable. This could reflect potential changes in the relative cost of debt capital depending on how nominal and real lending rates are affected by inflation. ${ }^{12}$ Finally, the local GDP is used as an instrument variable. Table 3 provides some descriptive statistics of the data.

\section{Empirical Analysis}

\subsection{Investigation Approach}

Our empirical identification strategy relies on the international variation in the taxation of corporate profits and personal capital income in 23 European countries. For the empirical analysis, we use the debt to assets ratio as our dependent variable. Subsequently, a simple empirical approach can be used to regress the company's debt ratio on the tax benefit of debt described by $\left(\tau_{i, t}^{C}+\tau_{i, t}^{D}\right)-\tau_{i, t}^{I}$ and a vector $X_{i, t}$ of firm- and country-level control variables. The subscript $i$ denotes the company and $t$ the year. Thus, the following empirical estimation can be set up:

$$
\text { Debt to Assets Ratio } \text { R }_{t, t}=\alpha_{0}+\alpha_{1}\left[\left(\tau_{i, t}^{C}+\tau_{i, t}^{D}\right)-\tau_{i, t}^{I}\right]+\alpha_{2} X_{i, t}+\delta_{i}+\gamma_{t}+\epsilon_{i, t} .
$$

12 A country-level indirect indicator for changes in interest rates is used, since our firm-level data do not provide reliable information on the companies' individual lending conditions. 
Global trends in company finance and business cycle effects are controlled by a time-fixed effect $\gamma_{t}$, and heterogeneity between companies is controlled by a company-fixed effect $\delta_{i}$. With regard to the tax benefit of debt, we expect a positive sign for $\alpha_{1}$.

Some firm-level characteristics such as losses or the share of tangible assets can serve as nondebt tax shields at the company level (DeAngelo and Masulis, 1980). The tax sensitivity with respect to the corporate tax rate $\tau^{C}$ should decrease with increasing tangibility, or if a company has a loss carryforward. Hence, in order to identify the effects of non-debt tax shields on the debt share, we use two interaction terms between the corporate tax rate $\tau^{C}$ and tangibility, as well as between $\tau^{C}$ and a dummy variable indicating companies with a loss carryforward. Thus, the following estimation equation can be used, for which we expect negative signs for $\alpha_{3}$ and $\alpha_{4}$.

$$
\begin{aligned}
\text { Debt to Assets } \text { Ratio }_{i, t} & =\alpha_{0}+\alpha_{1}\left[\left(\tau_{i, t}^{C}+\tau_{i, t}^{D}\right)-\tau_{i, t}^{I}\right]+\alpha_{2} X_{i, t}+\alpha_{3}\left(\tau_{i, t}^{C} x \text { Tangibility }_{i, t}\right) \\
& +\alpha_{4}\left(\tau_{i, t}^{C} x \text { LossCarryforward }{ }_{i, t}\right)+\delta_{i}+\gamma_{t}+\epsilon_{i, t} .
\end{aligned}
$$

An underlying assumption of the presented estimation equation is that every marginal variation of the relative tax benefit of debt, $\left(\tau^{C}+\tau^{D}\right)-\tau^{I}$, has the same impact on the debt share, irrespective of which of the components is changed. In additional regressions, we relax this assumption and estimate the effects for the three components separately: corporate tax rate, dividend tax rate and the tax rate on interest income. Then, equation (3) becomes

$$
\begin{aligned}
\text { Debt to Assets Ratio } \text { Ri,t } & =\alpha_{0}+\alpha_{11} \tau_{i, t}^{C}+\alpha_{12} \tau_{i, t}^{D}+\alpha_{13} \tau_{i, t}^{I}+\alpha_{2} X_{i, t}+\alpha_{3}\left(\tau_{i, t}^{C} x \text { Tangibility }_{i, t}\right) \\
& +\alpha_{4}\left(\tau_{i, t}^{C} x \text { LossCarryforward }{ }_{i, t}\right)+\delta_{i}+\gamma_{t}+\epsilon_{i, t} .
\end{aligned}
$$

We expect positive signs for the impact of the corporate tax rate $\alpha_{11}$, and for the impact of effective dividend taxation $\alpha_{12}$, while a negative sign for the impact of a higher interest $\operatorname{tax} \alpha_{13}$ can be expected. 


\subsection{Regression Results}

The empirical analysis is based on the investigation approach described in Section 4.1. We employ the fraction of debt in total assets as the dependent variable. First, we empirically test whether capital structure choices are affected by differences in the taxation of equity and of debt capital at the company- as well as at the shareholder level. A first set of regression results is presented in Table 4 . Since the tax data vary only at the country level, standard errors are clustered within country-year cells in order to avoid overstated significance levels (Bertrand, Duflo and Mullainathan, 2004; Moulton, 1990).

We begin with observations of stand-alone companies, i.e. companies which do not belong to a group of affiliated companies. Results based on this sample are shown in Table 4. In comparison to previous analyses such as that of Graham (1999) we are able to control for individual heterogeneity between companies, which might be correlated with the tax effects, by means of company-fixed effects. It should be mentioned that the companyspecific effects nest country-fixed effects and thus, remove cross-sectional heterogeneity between countries. In this manner, relatively time invariant country characteristics such as creditor rights or the type of banking system are entirely controlled for.

The amount of total assets is used as a control for the size of the company. However, the size of a firm's business activity may be endogenous, since the analysed opportunity to avoid taxes by financial planning may have an impact on the size of invested capital. For this reason, instrument variable (IV) estimations are carried out. At the first stage $\ln$ (Total Assets) is regressed on all exogenous variables and on the natural log of the country's GDP, where the firm is located. When controlling for the heterogeneity between countries, the variable $\ln (\mathrm{GDP})$ constitutes a suitable instrument, since GDP indicates the size of the local market. Hence, the correlation between invested capital and GDP originates from local economic opportunities. ${ }^{13}$ On the other hand, the debt ratio should not be directly

13 A more formal $t$-test reveals significance of the $\ln (\mathrm{GDP})$ at the $5 \%$ level in all first stage specifications. 
Table 4: Taxation and Financial Structure Choice

\begin{tabular}{|c|c|c|c|c|c|c|}
\hline & $(1)$ & $(2)$ & $(3)$ & $(4)$ & $(5)$ & $(6)$ \\
\hline$\tau^{C}+\tau^{D}-\tau^{I}$ & $\begin{array}{l}.289^{* *} \\
(.111)\end{array}$ & $\begin{array}{l}.311^{* * *} \\
(.115)\end{array}$ & & & & \\
\hline$\tau^{C}$ & & & $\begin{array}{c}.079 \\
(.105)\end{array}$ & $\begin{array}{l}.174^{*} \\
(.107)\end{array}$ & $\begin{array}{c}.143 \\
(.106)\end{array}$ & $\begin{array}{c}.007 \\
(.101)\end{array}$ \\
\hline$\tau^{D}$ & & & $\begin{array}{l}.270^{*} \\
(.141)\end{array}$ & $\begin{array}{l}.271^{*} \\
(.141)\end{array}$ & $\begin{array}{l}.272^{*} \\
(.140)\end{array}$ & \\
\hline$\tau^{I}$ & & & $\begin{array}{l}-.553^{*} \\
(.309)\end{array}$ & $\begin{array}{l}-.564^{*} \\
(.310)\end{array}$ & $\begin{array}{l}-.581^{*} \\
(.308)\end{array}$ & \\
\hline$\tau^{G}$ & & & & & $\begin{array}{l}-.146 \\
(.136)\end{array}$ & \\
\hline $\ln$ (Inflation Rate) & $\begin{array}{l}-.001 \\
(.002)\end{array}$ & $\begin{array}{c}.000 \\
(.002)\end{array}$ & $\begin{array}{l}-.001 \\
(.003)\end{array}$ & $\begin{array}{l}.000 \\
(.003)\end{array}$ & $\begin{array}{l}-.000 \\
(.003)\end{array}$ & $\begin{array}{l}-.003 \\
(.003)\end{array}$ \\
\hline Tangibility & $\begin{array}{l}.068^{* * *} \\
(.018)\end{array}$ & $\begin{array}{l}.144^{* * *} \\
(.016)\end{array}$ & $\begin{array}{l}.068^{* * *} \\
(.018)\end{array}$ & $\begin{array}{l}.131^{* * *} \\
(.014)\end{array}$ & $\begin{array}{l}.130^{* * *} \\
(.014)\end{array}$ & $\begin{array}{l}.130^{* * *} \\
(.014)\end{array}$ \\
\hline Profitability & $\begin{array}{c}-.131^{* * *} \\
(.030)\end{array}$ & $\begin{array}{c}-.131^{* * *} \\
(.030)\end{array}$ & $\begin{array}{c}-.129^{* * *} \\
(.030)\end{array}$ & $\begin{array}{c}-.130^{* * *} \\
(.030)\end{array}$ & $\begin{array}{c}-.131^{* * *} \\
(.030)\end{array}$ & $\begin{array}{c}-.127^{* * *} \\
(.030)\end{array}$ \\
\hline Loss Carryforward & $\begin{array}{l}.027^{* * *} \\
(.002)\end{array}$ & $\begin{array}{l}.059^{* * *} \\
(.008)\end{array}$ & $\begin{array}{l}.027^{* * *} \\
(.002)\end{array}$ & $\begin{array}{l}.057^{* * *} \\
(.008)\end{array}$ & $\begin{array}{l}.057^{* * *} \\
(.008)\end{array}$ & $\begin{array}{l}.057^{* * *} \\
.008)\end{array}$ \\
\hline $\ln$ (Total Assets) & $\begin{array}{c}-.003^{* *} \\
(.002)\end{array}$ & $\begin{array}{l}-.003^{*} \\
(.002)\end{array}$ & $\begin{array}{l}-.003^{*} \\
(.002)\end{array}$ & $\begin{array}{l}-.003^{*} \\
(.002)\end{array}$ & $\begin{array}{l}-.003^{*} \\
(.002)\end{array}$ & $\begin{array}{l}-.001 \\
(.001)\end{array}$ \\
\hline$\tau^{C} \mathrm{x}$ Tangibility & & $\begin{array}{c}-.238^{* * *} \\
(.068)\end{array}$ & & $\begin{array}{c}-197^{* * *} \\
(.068)\end{array}$ & $\begin{array}{c}-.195^{* * *} \\
(.068)\end{array}$ & $\begin{array}{c}-.191^{* * *} \\
(.068)\end{array}$ \\
\hline$\tau^{C} \mathrm{x}$ Loss Carryforward & & $\begin{array}{c}-.093^{* * *} \\
(.022)\end{array}$ & & $\begin{array}{c}-.089^{* * *} \\
(.021)\end{array}$ & $\begin{array}{c}-.088^{* * *} \\
(.021)\end{array}$ & $\begin{array}{c}-.086^{* * *} \\
(.021)\end{array}$ \\
\hline Adj. $R^{2}$ & .8449 & .8451 & .8449 & .8451 & .8451 & .8449 \\
\hline Observations & $3,162,461$ & $3,162,461$ & $3,162,461$ & $3,162,461$ & $3,162,461$ & $3,162,461$ \\
\hline
\end{tabular}

Dependent variable is the debt to assets ratio. Robust standard errors, which are clustered within countryyear cells, are indicated in parentheses. $\left.{ }^{*}\right),\left({ }^{* *}\right),\left({ }^{* *}\right)$ denote significance at the $(10 \%),(5 \%)$, and $(1 \%)$ level. A full set of firm and time dummies is included. All regressions are instrument variable (IV) estimations, for which the natural $\log$ of GDP is used as an instrument for $\ln$ (TotalAssets). Solely second stage regression results are presented.

affected by the growth path of the local market, in which the firm is located.

Columns (1) and (2) of Table 4 show the expected significant positive effect of the tax benefit of debt on leverage. In column (2) we test whether non-debt tax shields serve as substitutes for interest deduction at the corporate level. The statutory tax rate at 
the corporate level is interacted with both tangibility and the loss carryforward dummy variable. The results confirm the expected negative effect of a higher non-debt tax shield on the tax incentive to use debt. While controlling for the respective tax effects, the estimated coefficients of tangibility and having a loss carryforward, respectively, indicate positive effects of collaterals and losses on the financial leverage more clearly. Moreover, the positive effect of the tax benefit of debt on the financial leverage increases slightly.

The positive coefficients for the tax benefit of debt imply that companies increase their debt share with an increasing tax advantage of debt relative to equity. The estimated effect in column (2) of Table 4, for example, suggests that an increase of the tax benefit of debt by 10 percentage points leads to an increase of the fraction of debt by 3.11 percentage points. At first glance, the magnitudes of the estimated tax effects seem to be small. Non-tax factors such as agency costs, which we capture chiefly by the fixed effects estimator, seem to play an important role in practice. However, our elasticities are significantly higher in comparison to the previous literature based on US firm data. Graham (1999), for example, reports only a coefficient of 0.100 and Gordon and Lee (2001) report a coefficient of 0.057 for similar measures for the relative tax benefit of debt. ${ }^{14}$

Let us take a brief look at the other control variables used in the regressions. Our results do not suggest a significant impact of a country's inflation rate on the fractions of debt. Higher tangibility has a significant positive effect on the use of debt capital. The positive sign of the coefficient could result from lower agency costs, since tangible assets serve as collaterals. Profitable companies tend to lower their leverage significantly. Enhanced opportunities for internal financing could be one reason for that finding. Finally, a loss carryforward induces higher debt ratios. Since our variable is constructed as a historical earnings measure, this could be due to an alleviated equity base as a result of previous losses. However, if both variables also capture future economic perspectives, the result would be in line with the free

14 Comparing our results with previous studies we also find a higher elasticity of debt ratios. Evaluated at mean values of financial leverage and the tax benefit of debt, the elasticity of the debt ratio is 0.102 in the European case compared with 0.019 (Graham, 1999) and 0.024 (Gordon and Lee, 2001), respectively, in the US case. 
cash flow hypothesis (e.g., Stulz, 1990; Maloney et al., 1993). Since loss-generating firms probably feature worse investment opportunities, interest payments might be a suitable way of restricting management discretion (Jensen, 1986). As for the size of the company, we find a negative impact on leverage. While interpreting the results it should be noted that we use company-fixed effects, which already control for the mean size of the company.

In a second step, we decompose the tax benefit of debt and individually estimate the impact of the different tax components. The results are presented in columns (3) - (6) of Table 4, and confirm our theoretical expectations. We find a significant positive impact of the effective dividend-tax rate, as well as a negative impact of the tax rate on interest income on financial leverage. In conclusion, the significant effects of personal income tax patterns and the highly significant coefficients of the interaction terms confirm that both corporate and shareholder taxation do in fact matter for capital structure choices.

In column (5) of Table 4 we introduce the capital gains tax, $\tau^{G}$. However, no significant impact of capital gains taxation can be found. In additional estimations not presented here, we consider tax rates on capital gains in the case of non-qualified shareholding. The finding of an insignificant impact of capital gains taxation is confirmed by all these additional estimations. One may speculate whether this result is caused by the fact that a capital gains tax entails no additional tax burden. Merely a frontloading of tax payments can occur if it is possible to deduct the initial values of shares from the taxable amount of future personal capital income taxes.

In column (6) of Table 4 we neglect any impact of personal capital income taxes on capital structures and consider solely the corporate profit tax rate. Given the significant effects for the impact of dividend and interest taxation provided by columns (3) and (4), we are now facing at a possible bias if we do not control for personal capital income taxation. The regression result shows that the effect of the corporate tax rate is significantly biased if personal taxation is neglected. We estimate a downward biased and insignificant tax effect due to the omitted variables. This specification therefore clearly supports the view 
that personal income taxes should be considered when tax effects on capital structures are analysed.

In a third step, we focus on different groups to identify possible differences in tax sensitivities. From a theoretical point of view, we would expect a smaller impact of capital income taxation at the personal level on the financial decisions of larger companies with a higher number of shareholders. In the case of bigger companies with several shareholders, the decisions on the capital structure might be made by managers at the corporate level rather than at the shareholder level. Therefore, we carry out additional regressions where we distinguish between different types of companies. The results are presented in Table 5. We employ two specific company types: parent companies of a group of affiliated companies and the 25 percent smallest stand-alone companies in each of the considered years. The specific types of companies are denoted by a dummy variable, referred to as 'Company Type'. The 'Company Type' dummy equals one if a company fulfils the relevant characteristics, while zero if this is not the case. Subsequently, the interaction terms between 'Company Type' and the tax variables indicate differences in the tax effects for the respective company type in comparison to the basic effects of the whole sample. ${ }^{15}$

In the regressions shown by columns (1) and (2) of Table 5, we consider the stand-alone companies used in our previous analysis. The dummy variable 'Company Type' indicates the observations of the 25 per cent smallest stand-alone companies in each considered year. The results clearly support the expectation that smaller companies rely more on shareholder finance and thus, shareholder taxation becomes more relevant. Column (1) indicates a three times higher tax coefficient for the smaller companies of 0.489 in comparison to a coefficient of 0.163 for all stand-alone companies. This means that the capital structure of smaller firms reacts more flexibly to tax incentives. The results shown in column (2) also confirm that the leverage is affected by personal capital income taxes, especially

15 In order to handle possible technical problems arising from self-selection into one of the subgroups, we eliminate all observations of companies which switch between the respective sub-groups in different years. In this manner, a fixed-effects estimator leads to consistent results, since the company fixed-effect also controls for the selection into one of the sub-samples (see Verbeek and Nijman, 1992; Vella, 1998). 
Table 5: Different Groups of Companies

\begin{tabular}{|c|c|c|c|c|c|}
\hline & \multicolumn{5}{|c|}{ 'Company Type' Indicates ... } \\
\hline & \multicolumn{2}{|c|}{$25 \%$ Smallest } & \multicolumn{3}{|c|}{ Parent Companies } \\
\hline & $(1)$ & $(2)$ & $(3)$ & $(4)$ & $(5)$ \\
\hline \multirow[t]{2}{*}{$\tau^{C}+\tau^{D}-\tau^{I}$} & $.163^{*}$ & & $.308^{* * *}$ & $.310^{* * *}$ & \\
\hline & $(.090)$ & & $(.115)$ & $(.115)$ & \\
\hline \multirow[t]{2}{*}{ Company Type $\mathrm{x}\left[\tau^{C}+\tau^{D}-\tau^{I}\right]$} & $.326^{* * *}$ & & & $-.224^{* * *}$ & \\
\hline & $(.078)$ & & & $(.048)$ & \\
\hline \multirow[t]{2}{*}{$\tau^{C}$} & & $.214^{*}$ & & & $.174^{*}$ \\
\hline & & $(.132)$ & & & $(.107)$ \\
\hline \multirow{2}{*}{ Company Type $\mathrm{x} \tau^{C}$} & & .135 & & & $-.310^{* *}$ \\
\hline & & $(.107)$ & & & $(.141)$ \\
\hline \multirow[t]{2}{*}{$\tau^{D}$} & & .139 & & & $.271^{*}$ \\
\hline & & $(.112)$ & & & $(.141)$ \\
\hline \multirow[t]{2}{*}{ Company Type $\mathrm{x} \tau^{D}$} & & $.326^{* * *}$ & & & $-.184^{* *}$ \\
\hline & & $(.096)$ & & & $(.076)$ \\
\hline \multirow[t]{2}{*}{$\tau^{I}$} & & -.088 & & & $-.056^{*}$ \\
\hline & & $(.157)$ & & & $(.310)$ \\
\hline \multirow[t]{2}{*}{ Company Type $\mathrm{x} \tau^{I}$} & & $-1.11^{* *}$ & & & $.322^{*}$ \\
\hline & & $(.512)$ & & & $(.144)$ \\
\hline \multirow[t]{2}{*}{$\ln ($ Inflation Rate $)$} & -.001 & -.001 & .001 & .000 & .000 \\
\hline & $(.003)$ & $(.003)$ & $(.003)$ & $(.002)$ & $(.003)$ \\
\hline \multirow[t]{2}{*}{ Tangibility } & $.114^{* * *}$ & $.116^{* * *}$ & $.144^{* * *}$ & $.144^{* * *}$ & $.131^{* * *}$ \\
\hline & $(.030)$ & $(.029)$ & $(.016)$ & $(.016)$ & $(.014)$ \\
\hline \multirow[t]{2}{*}{ Profitability } & $-.163^{* * *}$ & $-.164^{* * *}$ & $-.131^{* *}$ & $-.131^{* * *}$ & $-.130^{* * *}$ \\
\hline & $(.025)$ & $(.026)$ & $(.030)$ & $(.030)$ & $(.030)$ \\
\hline \multirow[t]{2}{*}{ Loss Carryforward } & $.058^{* * *}$ & $.058^{* * *}$ & $.059^{* * *}$ & $.059^{* * *}$ & $.057^{* * *}$ \\
\hline & $(.013)$ & $(.013)$ & $(.008)$ & $(.008)$ & $(.008)$ \\
\hline \multirow[t]{2}{*}{$\ln$ (Total Assets) } & $-.005^{* *}$ & $-.005^{* *}$ & $-.003^{*}$ & $-.003^{*}$ & $-.003^{*}$ \\
\hline & $(.002)$ & $(.002)$ & $(.002)$ & $(.002)$ & $(.002)$ \\
\hline \multirow[t]{2}{*}{$\tau^{C} \mathrm{x}$ Tangibility } & $-.194^{* *}$ & $-.201^{* *}$ & $-.237^{* * *}$ & $-.238^{* * *}$ & $-.197^{* * *}$ \\
\hline & $(.100)$ & $(.097)$ & $(.068)$ & $(.068)$ & $(.068)$ \\
\hline \multirow[t]{2}{*}{$\tau^{C} \mathrm{x}$ Loss Carryforward } & $-.094^{* * *}$ & $-.092^{* * *}$ & $-.093^{* * *}$ & $-.093^{* * *}$ & $-.089^{* * *}$ \\
\hline & $(.035)$ & $(.035)$ & $(.022)$ & $(.022)$ & $(.021)$ \\
\hline Adj. $R^{2}$ & .8674 & .8674 & .8457 & .8457 & .8457 \\
\hline Observations & $2,085,250$ & $2,085,250$ & $3,181,931$ & $3,181,931$ & $3,181,931$ \\
\hline
\end{tabular}

Dependent variable is the debt to assets ratio. Robust standard errors, which are clustered within countryyear cells, are indicated in parentheses. $\left.\left(^{*}\right),\left({ }^{* *}\right),{ }^{* * *}\right)$ denote significance at the $(10 \%),(5 \%)$, and $(1 \%)$ level. All estimates include a full set of firm- and time dummies. Regressions are instrument variable (IV) estimations, for which the natural $\log$ of GDP is used as an instrument for $\ln$ (TotalAssets). Only second stage regression results are presented. 
in case of smaller companies. Thus, smaller firms seem to have less non-tax restrictions such as agency conflicts between shareholders and management.

The results depicted by columns (3) - (5) in Table 5 are based on an extended sample. In addition to all stand-alone companies, we now also consider companies that serve as a parent company of a group of companies. We consider parent companies rather than subsidiaries of a group of companies, because we believe that only parent companies have financing conditions that are fairly similar to those of stand-alone companies. ${ }^{16}$ The results of column (3) are similar to those based only on stand-alone companies in Table 4.

In columns (4) and (5) of Table 5 we proceed by dividing parent companies and stand-alone companies. Here, the dummy variable 'Company Type' is one, if a company is a parent company, and remains zero in all other cases. Column (4) shows a significantly smaller elasticity for parent companies with respect to the tax benefit of debt. More specifically, column (5) shows that parent companies are significantly less sensitive with regard to the corporate profit tax, the dividend tax, and the tax imposed on interest income. Since being organized by means of several affiliated companies can be interpreted as an indicator for bigger firms, it seems reasonable that personal taxes such as dividend and interest taxes are less important. The irrelevance of the corporate profit tax is surprising. This result can most likely be explained by enhanced tax planning opportunities at lower tiers of a group of companies, in particular in the case of a multinational group. If debt is distributed within the whole company group according to the relative level of taxation at different locations, tax effects on the fraction of debt cannot be identified by means of a fixed-effects estimator, which removes all cross-sectional variation between countries. ${ }^{17}$ Another explanation might be the fact that special-purpose entities are used as tax shelters (Graham and Tucker, 2006), and we cannot control for this kind of non-debt tax shields.

\footnotetext{
16 Personal taxation should be particularly less important for subsidiaries which use intercompany financing instead of external capital from individual investors.

17 Note that Huizinga, Laeven and Nicodème (2008), e.g., pool observations within parent-company cells in order to identify effects of the corporate tax rate on multinationals' capital structures.
} 


\section{Conclusion}

Theoretical considerations about companies' capital structure choices suggest that the total tax benefit of debt financing relative to equity taxation does in fact matter. We have empirically analysed the tax effects of both personal capital income and corporate profit taxation on capital structure choices using a comprehensive panel of firm-level data from 23 European countries in a standardised form. For each country and year during the period from 2000 until 2005, we have collected detailed tax rates for the corporate profit tax, dividend tax and taxes on interest income. We then calculated the tax benefit of using debt relative to equity financing.

Our basic empirical results identify a significant positive effect of the relative tax benefit of debt on the companies' debt ratio. The results suggest that differences in the tax levels of the return on equity relative to the tax on the return on debt capital do in fact play a significant role. The tax elasticity of the capital structure seems to be higher for our European sample than for US companies analysed in prior studies. Moreover, we can confirm substitutive relationships between non-debt tax shields and tax incentives to use debt. In a second step, we have decomposed the different tax components of the tax benefit of debt. Subsequently, we find a significant impact of the dividend tax rate and the tax imposed on interest income on companies' debt ratios. In principle, the results support the view that capital structure choices are significantly affected by personal capital income taxation. In a third step, we have finally focused on specific company types. Particularly, our results suggest that the debt ratios of smaller companies are more heavily affected by the tax benefit of debt. The 25 per cent smallest companies in our basic sample show a three times higher tax elasticity relative to all companies.

Finally, our results can be used to predict effects of tax reforms on companies' capital structure choices. In 2008 and 2009, for example, an important tax reform will take effect in Germany. In 2007, German corporate taxation was almost neutral with respect to 
different sources of finance, i.e. the tax benefit of debt was approx. zero. ${ }^{18}$ However, in 2009 the German tax system will undergo fundamental changes with respect to different sources of finance. The corporate tax rate in particular will be reduced and the German local business tax will be modified. However, the most important amendment with respect to financial decisions is the fact that the exemption of half of the dividends from personal capital income tax is abolished. As a consequence, the tax benefit of debt will increase heavily by approx. 19 percentage points. Let us consider specification (2) from Table 4. The point estimator for the impact of the tax benefit of debt on the fraction of debt suggests that an increase in the tax benefit of debt of about 19 percentage points will result in an increase of a company's leverage by 5.9 percentage points. Yet, in the case of small companies, specification (1) from Table 5 suggests that the German tax reform will lead to an increase of the leverage by approx. 9.3 percentage points.

Although our results are qualitatively in line with previous results in the literature, the magnitudes of the estimated tax effects exceed those found in previous studies. Furthermore, we find significant differences in the tax elasticity with respect to capital structure choices between different types of companies. Hence, the results suggest that the capital structures of companies are significantly affected by non-tax factors. Since tax planning by means of financial decisions still does not seem to be fully flexible, from a theoretical point of view it can be expected that underlying real investment decisions are also affected by taxation. However, an empirical analysis of this relationship remains an interesting challenge for future research.

18 In Germany, the tax benefit of debt depends on the multiplier of the German local business tax (Gewerbesteuer). For the purpose of this paper we always use the mean multiplier of municipalities which have a miniumum of 50.000 inhabitants each. In 2007, the mean multiplier was $432 \%$. 


\section{References}

Alworth, J. and G. Arachi (2001), The effect of taxes on corporate financing decisions: Evidence from a panel of Italian firms, International Tax and Public Finance 8, 353-376.

Alworth, J. and G. Arachi (2003), An integrated approach to measuring effective tax rates, Società italiana di economia pubblica, Working Paper.

Beattie, V., A. Goodacre and S.J. Thomson (2006), Corporate Financing Decisions: UK Survey Evidence, Journal of Business Finance and Accounting 33, 1402-1434.

Bertrand, M., E. Duflo and S. Mullainathan (2004), How much should we trust differencesin-differences estimates? Quarterly Journal of Economics 119, 249-275.

Buettner, T., M. Overesch, U. Schreiber und G. Wamser (2008), The Impact of ThinCapitalization Rules on Multinationals' Financing and Investment Decisions, Bundesbank Discussion Paper 03/2008, Frankfurt.

Buettner, T. and G. Wamser (2007), Intercompany loans and profit shifting - Evidence from company-level data, CESifo Working Paper 1959, Munich.

Chan, H., R. Faff and A. Ramsay (2005), Firm size and the information content of annual earnings announcements: Australian evidence, Journal of Business Finance and Accounting 32, 211-253.

Cooper, I.A. and K.G. Nyborg (2006), The value of tax shields IS equal to the present value of tax shields, Journal of Financial Economics 81, 215-225.

DeAngelo, H. and R.W. Masulis (1980), Optimal capital structure under corporate and personal taxation, Journal of Financial Economics 8, 3-29.

Desai, M.A., C.F. Foley and J.R. Hines (2004), A multinational perspective on capital structure choice and internal capital markets, Journal of Finance 59, 2451-2487.

Fernandez, P. (2004), The value of tax shields is NOT equal to the present value of tax shields, Journal of Financial Economics 73, 145-165. 
Fernandez, P. (2005), Reply to "Comment on the value of tax shields is NOT equal to the present value of tax shields", The Quarterly Review of Economics and Finance 45, 188-192.

Fieten, P., L. Kruschwitz, J. Laitenberger, A. Löffler, J. Tham, I. Vélez-Pareja and N. Wonder (2005), Comment on "The value of tax shields is NOT equal to the present value of tax shields", The Quarterly Review of Economics and Finance 45, 184-187.

Givoly, D., C. Hayn, A.R. Ofer and O. Sarig (1992), Taxes and capital structure: evidence from firms' response to the tax reform act of 1986, Review of Financial Studies 5, 331-355.

Gordon, R. and Y. Lee (2001), Do taxes affect corporate debt policy? Evidence from U.S. corporate tax return data, Journal of Public Economics 82, 195-224.

Gordon, R. and Y. Lee (2007), Interest rates, taxes and corporate financial policies, National Tax Journal 60, 65-84.

Graham, J.R. (1996a), Debt and the marginal tax rate, Journal of Financial Economics $41,41-73$.

Graham, J.R. (1996b), Proxies for the corporate marginal tax rate, Journal of Financial Economics 42, 187-221.

Graham, J.R. (1999), Do personal taxes affect corporate financing decisions? Journal of Public Economics 73, 147-185.

Graham, J.R. (2000), How big are the tax benefits of debt?, Journal of Finance 55, 1901-1941.

Graham, J.R. (2003), Taxes and corporate finance: A review, Review of Financial Studies $16,1075-1129$.

Graham, J.R. and A. Tucker (2006), Tax shelters and corporate debt policy, Journal of Financial Economics 81, 563-594.

Gropp, R.E. (2002), Local taxes and capital structure choice, International Tax and Public Finance 9, 51-71. 
Harris, M. and A. Raviv (1990), Capital structure and the informational role of debt, Journal of Finance 45, 321-349.

Harris, M. and A. Raviv (1991), The theory of capital structure, Journal of Finance 46, 297-355.

Huizinga, H., L. Laeven and G. Nicodème (2008), Capital structure and international debt shifting, Journal of Financial Economics, forthcoming.

Jensen, M. (1986) The agency costs of free cash flow: corporate finance and takeovers, American Economic Review 76, 323-329.

Jog, V. and J. Tang (2001), Tax reforms, debt shifting and tax revenues: multinational corporations in Canada, International Tax and Public Finance 8, 5-25.

Kale, J.R. and H. Shahrur (2007), Corporate capital structure and the characteristics of suppliers and customers, Journal of Financial Economics 83, 321-365.

La Porta, R., F. Lopez-de-Silvanes, A. Shleifer and R. W. Vishny (1997), Legal determinants of external finance, Journal of Finance 52, 1131-1155.

Lemmon, M.L., M.R. Roberts and J.F. Zender (2008), Back to the beginning: persistence and the cross-section of corporate capital structure, Journal of Finance, forthcoming.

MacKie-Mason, J.K. (1990), Do taxes affect corporate financing decisions? Journal of Finance 45, 1471-1493.

Maloney, M.T., R.E. McCormick and M.L. Mitchell (1993), Managerial decision making and capital structure, Journal of Business 66, 189-217.

Miller, M.H. (1977), Debt and taxes, Journal of Finance 32, 261-275.

Modigliani, F. and M. Miller (1958), The cost of capital, corporation finance, and the theory of investment, American Economic Review 48, 261-297.

Modigliani, F. and M. Miller (1963), Corporate income taxes and the cost of capital: a correction, American Economic Review 53, 433-443.

Moore, P.J. and F.P. Ruane, (2005), Taxation and the financial structure of foreign direct investment, IIIS Discussion Paper, Dublin. 
Moulton, B.R. (1990), An illustration of a pitfall in estimating the effects of aggregate variables on micro units, Review of Economics and Statistics 72, 334-338.

Myers, S.C. (2001), Capital structure, Journal of Economic Perspectives 15, 81-102.

Newberry, K. and D.S. Dhaliwal (2001), Cross-jurisdictional income shifting by U.S. multinationals: evidence from international bond offerings, Journal of Accounting Research 39, 643-662.

Rajan, R.G. and L. Zingales (1995), What do we know about capital structure? Some evidence from international data, Journal of Finance 50, 1421-1460.

Ross, S. (1977), The determination of financial structure: The incentive-signalling approach, Bell Journal of Economics 8, 23-40.

Shyam-Sunder, L. and S. Myers (1999), Testing static tradeoff against pecking order models of capital structure, Journal of Financial Economics 51, 219-244.

Stulz, R.M. (1990), Managerial discretion and optimal financing policies, Journal of Financial Economics 26, 3-27.

Vella, F. (1998), Estimating models with sample selection bias: a survey, Journal of Human Resources 33, 681-703.

Verbeek, M. and T. Nijman (1992), Testing for selectivity bias in panel data models, International Economic Review 33, 681-703.

Weichenrieder, A. (2006), Steuern und die Empirie der Unternehmensfinanzierung, Working Paper, Frankfurt. 